\title{
THE JANUS-FACE CATTLE RUSTLING IN PLATEAU STATE
}

\author{
KUDEN PLANG ISTIFANUS SHARPSPEAR \\ DEPARTMENT OF POLITICAL SCIENCE ABU ZARIA, NIGERIA \\ Kudenplangkat@gmail.com
}

Ali Subis Barilla

Department of political science Ahmadu Bello University Zaria, Nigeria. barill2015@gmail.com

DOI: 10.31364/SCIRJ/v7.i1.2019.P0119610

http://dx.doi.org/10.31364/SCIRJ/v7.i1.2019.P0119610

\begin{abstract}
This paper expounded the Janus-face cattle rustling in Plateau State. The paper technically unravels the peculiarity of cattle rustling in its dynamics, and the complex trend in Plateau State given the nature of the conflict in Plateau generally. To properly do this, queer ladder theory which posited as its main thrust that organised crimes happens in areas where there are slim livelihood opportunities, and that organised crimes are unconventional and weird means of socio-economic empowerment in the society is utilized. This is to establish the fact that cattle rustling in Plateau state is one dimension of the conflict in the State generally, and to ascertained the fact that spiral ethno religious conflict in Plateau in its trends and dynamics has resulted to the criminality of cattle rustling which is similar to human trafficking, drug cartels, prostitution and syndicated crimes and social disorder. The paper investigates the issue of cattle rustling and its socio-economics and political consequence. The paper also look into peculiarity of cattle rustling in America, Europe, Africa especially East Africa and Nigeria and concluded that, cattle rustling in Plateau takes both ethno religious and non ethno religious dimension in its trends and dynamics given the social category involved in the act either as a culprit or victim which differs from time, location, intent and complexity of the conflict within the state generally. It is evident that to a larger degree, cattle rustling in its early stage in Plateau manifested an ethno religious character but most recent it is manifesting non ethno religious character and in some cases and areas it is manifesting both given the causes and intent. This confirm the Janus-face of the act (cattle rustling) within the area of study.
\end{abstract}

Index Terms: Cattle raid, Cattle rustling, Ethnoreligious conflict, Janus-face cattle rustling, Conflict

\section{INTRODUCTION}

The incessant spiral ethno-religious conflict in plateau state has given birth to cattle rustling which took different forms and shapes in its dynamics within the area. Since the return of democratic civilian rule in Nigeria from 1999 to date the menace of Cattle rustling accompanied the socio economic and the political decadence that befall and bedevilled the country challenging political and social order of the country. In the dynamics of Cattle rustling in plateau state two different trends were noticed which keeps on changing 'face' in the vicious circle of conflict and cattle rustling within the area.

Cattle rustling took an ethno-religious phase in its genesis where it was purely the Fulani herders Who are predominantly Muslims versus the Christian divisive ethnic groups within the area, this Period span from 2004 to 2009. The second phase of cattle rustling is the non-religious-ethnic Phase which raised its 'ugly face' around the period of 2009/2010. This phase gives cattle rustling the look and shape of an organised crime equivalent to drug cartels, syndicates, human trafficking, economic crime and a form of ethno religious conflict at the same time, the reason being that in different parts of the state the reason and causes of cattle rustling differs 
from time to time. This gives the menace of cattle rustling a Janus-face in its dynamics within the area. One vital thing to note is the value of cattle, cattle has high market value, nutritional value, social value, traditional value, and agricultural value among others within the area. It is these values accrued to cattle that propels the menace of cattle rustling and its changing nature. This paper is divided into six sections. The first section covers abstract and introduction; the second section covers the theoretical framework, the third section look into conceptual clarification, the fourth section is the body of literature side by side analysis, the fifth section centre on critique while the six sections is the summary and conclusion.

\section{THEORETICAL FRAMEWORK}

Theory is the combination of logical explanations used to explain a particular event. The discuss is guided by queer ladder theory. Queer ladder theory was propounded by an American sociologist by name Daniel Bell (1919-2011).the cohorts of Daniel Bell include Downes and Rockes 1988 and Parkhurst 1990 among others. Based on the origin of the theory, the idea of the queer ladder was introduced in an attempt to explain the functional significance of organized crime as a desperate tactic for socioeconomic empowerment and social climbing. The theory was propounded in 1953 by Bell (1919-2011) in an essay "On the way of crime", which presents the classic formation of the queer ladder of mobility. Daniel Bell explains the entry of Italian American criminals into organized crime (1953) and posited that the Italian community has achieved wealth and political influence much latter and in a harder way than previous immigrants group in America. He finds out that there exist few open routes to wealth (livelihood opportunities) and social climbing and that makes some turn to illicit ways of getting rich.

\section{Basic Assumptions of Queer Ladder Theory}

1. Organized crime is an instrumental behaviour or a practice; it is a means to an end.

2. Organized crime is an instrument of social climbing and socioeconomic advancement.

3. Organized crime is a means to accumulate power.

4. Organized crime is mostly found in places with limited or slim livelihood opportunity.

5. Organized crimes are more common in societies where there is no strong adherence to law and enforcement of law (systems or governments with high level of corruption).

\section{ORGANISED CRIME}

\section{CONCEPTUAL CLARIFICATION}

An organised crime is a criminal enterprise involving discernible hierarchical social networking and syndication.

\section{CATTLERAID}

cattle raids which is also seen as an act of stealing cattle from one community by another without destroying property or killing people.

\section{CATTLE RUSTLING}


Cattle rustling has been defined by so many scholars over time. Cattle rustling could be seen as an act of stealing of grazing cattle. Historically, the term cattle rustling has United States of American origin, the term was used within the context by pioneer farmers who lost their cattle while grazing on huge ranges that were difficult to patrol for policing. Cattle rustling has been geared by criminal motive to expropriate cattle for meat or for commercial purposes (sale) (Blench, 2004).

The concept cattle rustling is understood alongside cattle raids which is also seen as an act of stealing cattle from one community by another without destroying property or killing people.

In the periods before the 1990 cattle raids are purposely to steal livestock, by scaring away the owners, but cattle rustling involve destruction of property and murder. (Cheserek, Omondi, \&Odenyo 2012, Kipkorir, \& Welbourn,1973).

Furthermore, in the recent time as opposed to the traditional as among the Masaai, Pokots and the Marakwet people of Kenya among others. The practice of cattle-rustling has been defined to mean, 'the stealing or planning, organizing, attempting, aiding or abetting the stealing of livestock by any person from any country or community where the theft is accompanied by dangerous weapons and/ or violence. The act of cattle-rustling mainly involves and affects the pastoral communities their borders. (Kenya human rights commission, 2010).

One imperative thing to note about the distinction between cattle raid and cattle rustling is that, in the periods before the 1990 cattle raids are purposely to steal livestock, by scaring away the owners, but cattle rustling involve destruction of property, and murder with the number of stolen cattle ranging from 50 to300 and above involving the use of sophisticated arms and violence (Cheserek, Omondi, Odenyo 2012, Kipkorir, Welbourn, 1973, \& The Nation $30^{\text {th }}$ March, 2014). It is good to note that there is a little distinction between cattle raid and cattle rustling in this context, but the two terms are equally used interchangeably including cattle theft based on context.

BODY

Cattle rustling have been in existence over seventy thousand years ago, it was consider as part of the culture of the cowboys in ancient days, but was still seen as a heinous crime with death penalty by hanging when caught by the vigilante. The act of cattle rustling caries different names in different parts of the globe, it is called duffing in Australia and the culprits are refers to as duffers, it is also known as rustling in America while the culprits are called rustlers. Historically, cattle rustling is one of the major issues during the American civil war (1861-1865), most conflicts between counties were alleged to cattle rustling which also was one of the major challenge of the law enforcement agencies (Derricourt, \& William, 1899).

It was also recorded that during the Second World War cattle rustling was one of the major issues challenging the political, social and economic order of the United States of America which led to formation of Mccaran act in 1941, the act stipulated that there should be fine for the transportation of stolen cattle. As a result of challenges cattle raisers find within the American system in the early 
twentieth century, the Texas and South Western cattle raisers Association employed field inspector to police cattle rustling, this agent was deputized by the Texas Department of Public Safty and the collaboration of the two agencies help Texas rangers to recover four thousand $(4,000)$ cattle in 1993. In late 1970s it was also recorded that there emerged another form of cattle rustling within the American system which is known as suburban rustling, this form of cattle rustling is similar to the trans-border form (dimension) of cattle rustling happening between Ethiopia and Uganda, where cattle rustled in Ethiopia are transported to Uganda by the rustlers to be disposed safely, and the ones rustled in Uganda are also transported to Ethiopia for safe disposal, but the differences is that the suburban rustling take place within a particular country while the trans-border rustling take place across the border of two or more countries (Mccaran act 1941, 1994).

In the ancient Europe, cattle rustling was also used as a means of declaring war against principalities and a response of retaliation signifies self defence by a belligerent principality. Around the region of Argentina in time past cattle were rustled from Andes and other areas to Chile and exchange for alcoholic beverages and weapons. In 2013 following the rustling of 300 cattle the federal government of Scotland declared cattle rustling as an issue of national emergency due to its devastating effect on livelihood opportunities and national security (Derricourt \& Williams 1899, Blench, 2004, \& Daily Trust Editorial, 05 February, 2014). According to Cheserek, Omodi, \& Odenyo (2012), in Africa cattle rustling was culturally practice among the Marakwet and the Pokot people of Kenya whom are pastoralists by occupation. The Marakwet and the Pokot people traditionally practiced cattle raids with other neighbouring communities as a tradition and part of their culture, they use traditional weapons such as; sticks, spears, bows, arrows and clubs. These traditional cattle rustling(cattle raid) among the Marakwet and Pokot people of Kenya are practiced as an act of reciprocity and means of acquisition of wealth (cattle), this is because herding is their major economic activity and means of livelihood. Poor families among the Marakwet and the Pokot people uses cattle rustling to acquire cattle most especially after droughts and other disasters like disease and plagues, cattle rustling is also a form of communal conflict among the Masaai, Pokot and the Marakwet people of Kenya among other herders in the East African region. It is point out that in 1990s the cattle raid which is usually known as a cultural practice among the Marakwet and the Pokot people change and take the form of cattle rustling in the sense that instead of the use of traditional weapons like sticks, spears, bows, arrows and clubs the main weapons became sophisticated arms like AK47and the act also metamorphosed into an organized crime or violence. In the period before 1990 (Cheserek, Omodi, \& Odenyo2012) observed that among the East African herders cattle raids are meant to steal livestock, by intimidating the owners of the cattle. On the other hand cattle rustling which is seen as a modern form of organized cattle raid is characterized by destruction of property and loss of lives. Cattle rustling have become a form of conflict, organized crime, and a commercial venture along the boundaries of pastoral communities and stolen livestock are never recovered. It is also noted that cattle rustling is associated to politically connect and those 
who are in possession of authority, the personalities of the culprits sometimes is not only the herders. Cattle rustling menace has cause a lot of destruction of lives and properties among the Marakwet and Pokot herders of Northern Kenya. It is significant to note that the issue that led to the change from traditional cultural cattle raid to cattle rustling among the Marakwet and Pokot people is the proliferation of illegal weapons and commercial gains among the Pokot and the Marakwet people. As observed in the periods before 1990s, the Marakwet people and the Pokot people used different traditional weapons, the Marakwet people utilizes their traditional weapons like clubs, bows, poisoned arrows and swords while the Pokot people also uses their traditional weapons like sticks, spears, bows and arrows. The weapons used by the Pokots and the Marakwet people are traditionally similar with a little distinction (Kaprom, 2013).

By way of historical evidence, the transformation from cattle raid to cattle rustling among the Pokot and the Marakwet people was traced as resulted from conflicts along Kerio River, in this conflict the Pokot people where labelled as the aggressor for invading the grazing land of the Marakwet people. As a resultant of this raid the Marakwet people were geared to acquire modern sophisticated weapons to counter the Pokot people and to also raid other neighbouring herders within the region. To signify that the act of cattle raid was a cultural phenomenon among the Pokot and the Marakwet people, it was noted that the gun suppliers of the Marakwet people were members of the Pokot people. It is estimated that there were 1,000 sophisticated modern arms found in possession of the Marakwet warlords (Cheserek, Omodi \& Odenyo, 2012, Al Chukwuma, \& Francis, 2014). This scenario glaringly shows how the traditional cultural cattle raid among the Pokot and the Marakwet people of Northern Kenya metamorphosed into modern organized cattle rustling through the used of sophisticated modern weapons.

\section{Cattle Rustling in Nigeria}

Contrary to the view of Cheserek, Omodi, \& Adenyo (2012) cattle rustling in Northern Nigeria particularly Plateau State is not cultural but as the result of ethno religious conflict which is sometimes seen as conflict between indigenes and non-indigenes which has also manifested in different forms and context. On several occasions in Jos, the two groups have fought over political issues and political positions. Some times the conflict is over land and access to other resources. Another phase of the conflict is the presence of Fulani cattle herders in some parts of Plateau State. The Fulani, who are nomadic and predominantly Muslim, are often attacked by the indigenes because they allow their cattle to graze on their land and cause damage. There have been numerous cases of cattle rustling, where cattle belonging to Fulani have been stolen by members of indigenous communities, leading to reprisal attacks by Fulani on these communities, followed by counter-attacks by these communities against the Fulani, which gives cattle rustling an ethno-religious look and an organized economic criminal look at the same time. On the other hand, recently in Mangu Local Government Area and some parts of the state, the victims and the culprits of cattle rustling are ethnically and religiously mixed (both Fulani and the indigenous ethnic groups). The reason is that there exist indigenous ethnic 
groups within the area who are herders apart from the Fulani. Cattle rustling and the dispute between the Fulani and other communities can be seen as a sub-conflict within the broader conflict in Plateau State, but soon the two became intertwined. This is because it was earlier noted that the Tarok ethnic group were the first culprits of cattle rustling in Plateau State who rustled the cattle of the Fulani as a reprisal attack in response to the attack which took place within that area, while in Mangu local government area, both the victims and the culprits of cattle rustling are mixed simply because there exist indigenous victims and culprits of cattle rustling apart from the Fulani. Recently Cattle rustling is primarily motivated by the economic gain, as the sale of cattle became a lucrative business, cattle rustling was religiously based conflict between the Fulani and Christian ethnic group in the beginning, but in recent time it transcend the religious line and became a threat and an enemy to the whole state, both the victims and the rustlers are Christians and Muslim ethnic groups not only the Fulani ethnic group nor the indigenous people alone. Cattle are the main source of livelihood of the Fulani and other herders and it plays an important economic, social and cultural role in their lives. As the Fulani fought back against the Tarok and other predominantly Christian groups whom they suspected of stealing their cattle, the religious dimension came into play. As most Fulani are Muslim, Christian indigenes associated them with their other Muslim antagonist particularly the Hausa. The Fulani claim to have lost over 1,800 human lives and 160,000 cows between September 2001 and May 2004 (Human rights news watch report, 2004).

To buttress the fact that cattle rustling in Plateau State started as a form of ethno-religious conflict, Abubakar (n.d) noted that:

With the on-set of the conflicts in Plateau State in 2001 a number of Fulani community leaders and herders were killed. A large number of livestock were burnt or killed. Cattle rustling have been a major cause of the most recent conflict in the Southern part of the State. As a result a large number of the cattle herders along with their animals fled from the State to the neighbouring States of Bauchi, Nassarawa, Kaduna and the Federal Capital Territory.

The above facts show the dialectics and the changing face of cattle rustling in Plateau state as a region where the area of study (Mangu local government area) is located. The literature above reveals that cattle rustling is a phenomenon which evolves over time and takes different forms depending on location. As posited by Cheserek, Omodi, \& Odenyo (2012). Cattle rustling among the Marakwet and the Pokot people in Kenya came about as a result of cultural practice and rivalry, while in the northern Nigeria most especially Plateau State, cattle rustling came about as a result of ethno-religious conflict and later took a non ethnic and non religious 'face'. It is of note that cattle rustling is as a result of proliferation of arms and that cattle rustlers engage in the activity because of the economic gain. The two authors also noted that cattle rustling have impact on the livelihood of victims and the cattle rustling culprits.

Historically, it could be deduced that cattle rustling most especially among the cowboys has cultural connotation which also corroborated with the Marakwet and the Pokot people of Kenya whom cattle rustling was a cultural event to demonstrate an act of bravery and superiority among others under the control of elders. Conflict can take a form of cattle rustling as witnessed in Plateau 
State where cattle rustling is both a cause and an effect of conflict, this is also the same with what happen during the American civil war (1861-1865) as discussed.

Drawing further inference from the above, we can equally posit that historically, cattle rustling in ancient Europe most especially in America and Argentina, Africa most especially in Kenya Uganda, Lesotho and northern Nigeria especially Jos Plateau has similar attributes with little distinction in their genesis and motives which is either cultural, ethno-religious, organized crime, form of violence, transnational and economical among other things, which also impacted on the livelihood of individuals either as a culprit or a victim and the society at large (Cheserek, Omodi, \& Odenyo 2012, Abubakar (n.d), Human rights news watch report, 2001, Derricourt, \& William, 1899).It is also of note that cattle rustling is key in the vicious circle of conflict in Plateau State because it is notice that recent attacks are as a result of cattle rustling. It is also evident that cattle rustling in Plateau State is the recent multiplier effect of the spiral conflict within the state. In another way it is revealed that cattle rustling is associated with conflict because it is triggered by arm proliferation, and it is also seen as a form of conflict which takes different 'faces' of either ethno religious or non ethno-religious and economical 'face' among others as in the case of Northern Nigeria most especially in Jos Plateau where the study is located.

Cattle rustling is a 'two faced' sub conflict within the broad ethno religious conflict in plateau state. One indispensable thing to note about the Janus-face of cattle rustling in Plateau State is that when cattle rustling is analyzed on the bases that the act is ethno religious incline in the long run of the analyses it runs through the other part of the argument that is non ethno religious or organized crime phase, the reason being that in either case there exist economic intent behind cattle rustling, another issue is that the reason for cattle rustling differs from day to day and place to place within Plateau State. This reveals the complex dynamics within the trends of cattle rustling in Plateau State. In the Janus face analyses of cattle rustling in Plateau State is like the augment of the egg and the hen which one precedes the other? This confirms the Janus face of cattle rustling in Plateau state which is ethno religious on the one hand and non ethno religious on the other hand.

\section{CONCLUSION}

This study investigates the janus face of cattle rustling in Jos Plateau, which finds out that the issue of cattle rustling in Jos Plateau in the beginning took an ethno religious dimension but along the line following the dialectics and the complexities of conflict within the state metamorphosed to a non ethno religious organised crime. This is similar to the perspectives of cattle rustling as forwarded by AL chukwuma \& Francis (2014) which posited that the two perspectives of cattle rustling are the terror brand and commercial perspectives of cattle rustling. With regards to the janus face of cattle rustling in Jos Plateau, the changing face is recurrent, and changes with location, time and causes (intent) because the causes varies with location and time within the state which also makes 
cattle rustling instrumental to the vicious circle of conflict within the state. It is also the major propeller of the recent Jos Plateau conflict shift from urban to rural areas within the state.

\section{REFERENCES}

[1] Abubakar,M. (n.d). The impact of conflict on the economy: the case of plateau state of Nigeria.

[2] Blench, R. (2010). Conflict between Pastoralists and Cultivators in Nigeria: Review paper Prepared for DFID,Nigeria.

[3] Cheserek, Omondi, and Odesnyo (2012). Nature and Causes of Cattle Rustling among some Pastoral Communities in Kenya. Department of Applied Environmental Social Sciences, Chepkoilel University College, Eldoret, Kenya. Daily Trust editorial 5 th February 2014.

[4] Derricourt, W. (1899) Old Convict Days (2nd ed.) T.F. Unwin, London.

[5] Human Rights Watch Report "Jos city turn apart” December (2004).

[6] Kaprom T. (2013). Effects of Cattle Rustling on Economic Development : A case of Masol location, West Pokot county. Kenya.

[7] Kenya Human Rights Commission [KHRC].2001. Raiding Democracy: The Slaughter of the Marakwet in the Kerio Valley. Nairobi: KHRC.

[8] Lyman D. and Gary W. (4th ed). (2007). Organized Crime. Prentice hall. Mccarant act 1941 and 1994.

[9] Okoli, AL Chukwuma and Opeleke, Francis. (2014). Cattle rustling and the dialetics of security Political Science, Federal University Lafia, Nasarawa State, Nigeria (2)3.

[10] Okoli, A. and Orinya, S (2013). Oil pipeline vandalism and Nigeria's national security. Global Political Science), 13 (3:1.0), pp. 37446. The Nation 30th , March 2014. in Nothern Nigeria. Department of Journal of Human Social Sciences (F: 